\title{
透析患者の妊娠と分婏の看護
}

\author{
風間 真理子坂田佐代子松本邦子 \\ 鈴木亨下条文武荒川正昭 \\ 新潟大学人工透析部 \\ (昭和 61 年 10 月 29 日受付)
}

key words : chronic hemodialysis, pregnancy, delivery

〈要旨〉

慢性血液透析患者が妊娠して児を得ることは困難と考えられているが, 今回私達は, 2 回目の妊娠が無事継続して 分婏に至り, 母児共に順調な経過をとっている 1 症例（31 歳, 女性 : 透析歴 3 年）を経験したので, 看護面より若干 の検討を加えて報告する。

初回出産は透析 2 年目であるが妊娠 26 週に辺縁洞破裂のため早産した. 児は $880 \mathrm{~g}$, 未熟肺のため 17 時間後に死 亡した。透析 3 年目再度好娠し, 妊娠 16 週目腹部緊満症状が出現し, 産科へ入院した. 初回の経験を踏まえて, 最低 妊娠 32 週まで継続させることを目標に, 透析室と産科で協力体制をとった. 私達は, 1) 妊娠の継続を計り, 母児と もに最良の状態で分婏に臨めるよう援助することと， 2 ) 不安と苦痛の緩和に努めることを看護目標にあげた. 看護 上の問題点として，1）子宮筋収縮による腹部緊満症状がある，2）透析中に血圧低下が起きる，3）胎児に対する 不安がある，4）全身搔痒感と長時間透析による苦痛があるなどをあげ, これらの問題点を中心に看護を展開した。 看護面としては, 妊娠 20 週頃から透析中に血圧低下と腹部緊満がみられたが, 注意深い綿密な観察に努め, 透析を十 分行えるように検討を重ねて対処した。 また胎児に対する不安や透析中の苦痛があるため, 年れらを少しでも緩和さ せ，夫や家族とともに励ましたことが重要であった。全身の蛋痒感は妊娠中の肝機能障害とともに現われたが, 分婏 後に消失した。患者は, 妊娠 34 週に経胵分婏にて, $1,802 \mathrm{~g}$ の男児を出産した. 母児ともに順調な経過を辿り, 現在 に至っている.

\section{Nursing for pregnancy and delivery in a chronic hemodialysis patient}

Mariko Kazama, Sayoko Sakata, Kuniko Matsumoto, Satoru Suzuki, M. D., Fumitake Gejyo, M. D. and Masaaki Arakawa, M. D.

Kidney Center and Department of Medicine (II), Niigata University, School of Medicine

Although it is thought that female patients on chronic hemodialysis have much difficulty in becoming pregnant and bearing a child, we recently experienced a 31-year-old woman on 3-year hemodialysis, whose second pregnancy continued uneventfully leading to the delivery of a child with subsequent normal courses of both the mother and child. We report this case, with some additional considerations from the viewpoint of nursing.

Her primiparity occurred during the second year of hemodialysis, but at the 26th week of pregnancy she prematurely delivered because of a rupture of the marginal sinus. The baby, weighing $880 \mathrm{~g}$, died 17 hours after birth due to premature lungs. During the third year of hemodialysis she became pregnant again and entered the department of obstetrics before the onset of abdominal turgescence at the 16th week of pregnancy. In view of the experience with regard to her primiparity, a co-operative system was established between the dialytic room and the department of obstetrics, with the aim of continuing pregnancy until the 32 nd week at least. Then, from the viewpoint of nursing, we aimed at 1) continuing the pregnancy and helping both the mother and child to face delivery at their best conditions, and 2) making efforts to alleviate her anxiety and pain. Nursing points included 1) abdominal turgescent symptom due to uterine muscular contraction, 2) occurrence of hypotension during 
hemodialysis, 3) anxiety about the child, and 4) generalized itchy sensation, and pain due to prolonged hemodialysis. These points being taken into consideration, the nursing was developed as follows : From about the 20th week of pregnancy, hypotension and abdominal turgescence appeared during hemodialysis, which we controlled through both careful and close observations and repeated examinations, permitting us to perform satisfactory hemodialysis. Anxiety about the child and pain during hemodialysis were alleviated as far as possible, and it was very important for both her husband and family to encourage her. Together with liver dysfunction during pregnancy, a generalized itchy sensation appeared, which, however, disappeared postnatally. The patient was transvaginally delivered of a boy weighing $1,802 \mathrm{~g}$ at the 34 th week of pregnancy. Both mother and child are now doing well with uneventful courses.

\section{はじめに}

一般に慢性血液透析患者が妊娠し児を得ることは困難 と考えられており，これまで我国においては数例の報告 があるに過ぎない ${ }^{1 \sim 7)}$. 今回私達は, 2 回目の妊娠を継続 させて無事出産を行い，母児ともに順調な経過をとって いる 1 症例を経験したので, 看護面より検討し若干の知 見を得たので報告する。

症例

症例 : 31 歳, 家族構成:夫, 31 歳

性格：自己主張が強く, 感受性豊かである. 理解力：良 好. 資格：

現病歴：昭和 45 年, 慢性腎炎と診断され, 通院治療を 受けていたが腎機能障害が徐々に進行し, 昭和 57 年 3 月 血液透析に導入した。 今回の入院まで週 3 回, 1 回 5 時 間の透析を行っている.

月経歴, 妊娠歴: 初潮 14 歳, 結婚 20 歳. 月経周期 29〜40 日型, 期間 7 日間.

昭和 52 年初めて妊娠したが, ネフローゼ症候群のため
人工妊娠中絶術を行った。昭和 58 年 10 月妊娠と判明, 翌昭和 59 年 3 月 28 日, 妊娠 26 週 6 日に, 辺縁洞破裂に より早産し, $880 \mathrm{~g}$ の男児を出産した。览は未熟肺のため 17 時間後に死亡した。同年 11 月再度妊娠と診断された が，挙児願望が非常に強いため継続に踏み切った。昭和 60 年 2 月 6 日, 妊娠 16 週に腹部緊満が出現したため本 院産科に入院した.

入院中の経過：妊娠中の経過を図 1 に示した。尿はほ とんど無尿であった。体重増加は分婏まで $8 \mathrm{~kg}$ の増加を 認め,それに伴ってドライウェイトも段階的に設定した。 妊娠 20 週頃より, 透析中に血圧低下がみられるように なった。また，羊水過多が認められ，羊水穿刺を合計 11 回 $(4,450 \mathrm{~m} l$ 除去) 行った.さらに妊娠 22 週には子宮頸 管縫縮術を行った。塩酸イソクスプリン(ズファジラン) の点滴静注と硫酸テルブタリン（ブリカニール）の内服 により腹部緊満を押さえた。

血清尿素窒素抢よびクレアチニンの透析前值をできる だけ低值に押さえ，ヘマトクリット值を $30 \%$ に維持する

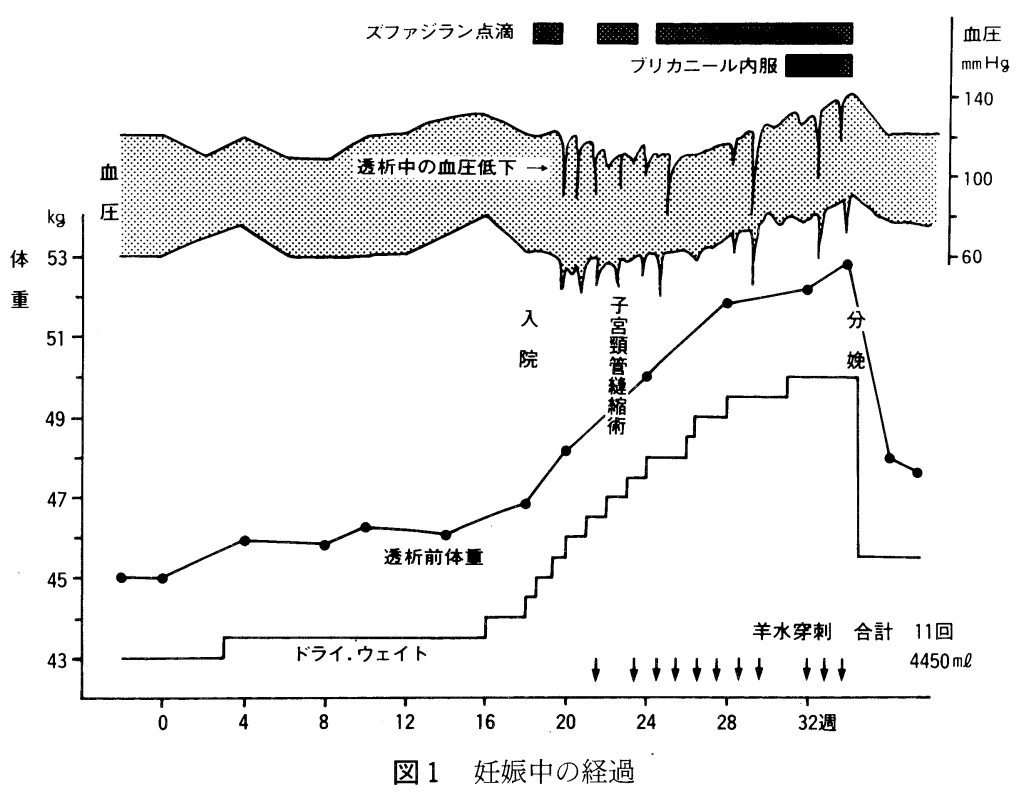


表 1 看護上の問題点と看護計画

\begin{tabular}{|c|c|}
\hline 看護上の問題点 & 看 護 計 \\
\hline $\begin{array}{l}\text { 1. 子宮筋収縮による腹部緊満症 } \\
\text { 状がある }\end{array}$ & 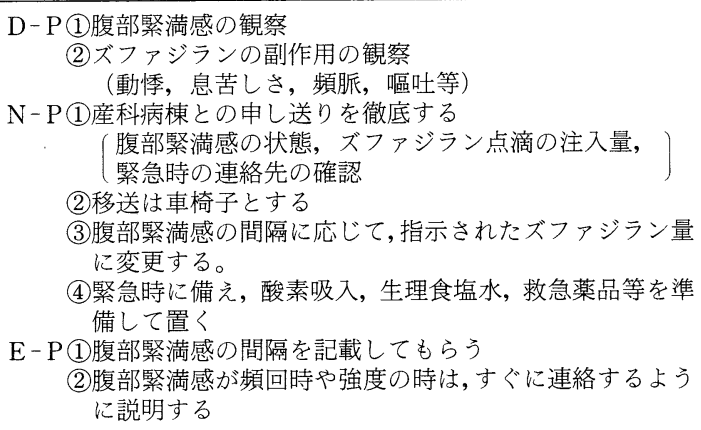 \\
\hline 2. 透析中に血圧低下が起きる & $\begin{array}{l}\text { D-P(1)前駆症状の観察 } \\
\text { (噯気, 気分不快, 嘔気, 頻脈, 冷汗等) } \\
\text { N-P(1)症状に応じたバイタルサイ頻回測定を行う } \\
\text { (2)血圧低下時は,透析条件を下げて直ちに生理食塩水の注 } \\
\text { 入を行う } \\
\text { (3)貧血の予防と早期発見に努める } \\
\text { (検査データをを把握, 輸血の準備) } \\
\text { (4)十分な透析ができない場合は対策を検討する } \\
\text { E-P気分不快時は, 早めに連絡するように説明する } \\
\text { (2)貧血予防の食事指導を行う }\end{array}$ \\
\hline $\begin{array}{l}\text { 3. 胎児に対する不安 (再度, 未 } \\
\text { 肺熟児が生れる) がある }\end{array}$ & $\begin{array}{l}\text { E-P(1)妊娠を継続することで, 胎児の肺が成熟するため妊娠 } \\
32 \text { 週を目標に頑張るように説明し，夫や家族にも患者 } \\
\text { を励ますように動きかける }\end{array}$ \\
\hline $\begin{array}{l}\text { 4. 全身搔痒感と長時間透析によ } \\
\text { る苦痛がある }\end{array}$ & 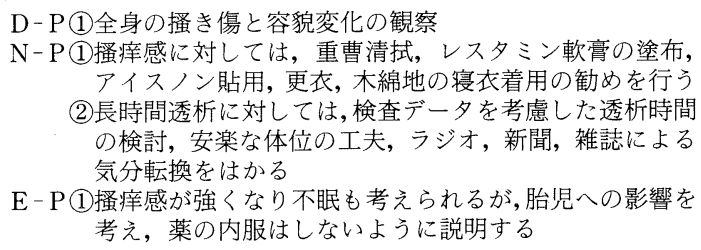 \\
\hline
\end{tabular}

$\mathrm{D}-\mathrm{P}$; diagnosic plan

$\mathrm{N}-\mathrm{P}$; nursing plan

$\mathrm{E}-\mathrm{P}$; education plan
ことを目標として, 週 3 回， 1 回 5 時間の透析を，妊娠 9 週目より週 3 回・ 1 回 6 時間に, 妊娠 17 週目よりさら に 1 回 3 時間を追加し, 妊娠 26 週目より週 4 回・ 1 回 6 時間, 妊娠 31 週目より週 5 回・1 回 5 時間と増加させた. 妊娠 33 週目の分婏直前には, 血圧低下と腹部緊満が著し いため ECUM 療法を週 2 回追加して除水した。

輸血は, 経過中に合計 24 単位行った。食事は自由食を 原則として，病院食の他に間食も許可したが，透析間の 体重増加は $2 \mathrm{~kg}$ 前後であった.

一方，妊娠の経過中に肝機能障害もみられた．妊娠 16 週頃より総コレステロール, 中性脂肪, GOT, GPT, ALP, LAP などが上昇し, 妊娠 30 週頃に急速に高值を示した が, 分婏後は速やかに下降した. それに伴って増強して いた全身の搔痒感も分婏後は消失した。

胎児の成熟度は，超音波断層法により計測した児頭大
横径で評価したが，正常範囲内であった。妊娠 34 週 1 日 目, 母体の肝機能障害と胎児の肺成熟度を考慮のうえ, 分婏誘発に踏み切り, 経胵分婏にて $1,802 \mathrm{~g}$ の男児を出 産した. Apgar score 9 点, 出血量 $447 \mathrm{ml}$ であった. 児は自発呼吸良好で, NICUへ収容された。

\section{看護の展開}

1. 看護目標

1 ）妊娠の継続を計り，母児ともに最良の状態で分婏 に臨めるように援助する。2）不安と苦痛の緩和に努め る.

2. 看護上の問題点と看護計画：表 1 に示した。

3.看護の実際と結果

1) 子宮筋収縮による腹部緊満症状がある.

2 ）透析中に血圧低下が起きる.

図 2 は腹部緊満感と血圧低下がみられた典型的な 1 日 
の経過を示した，腹部緊満感が出現する間隔は患者自身 に記録してもらい，その間隔に応じて，指示された塩酸 イソクスプリン量に変更した。塩酸イソクスプリンの副 作用や血圧低下の前駆症状として，息苦しさ，動悸，頻 脈などがみられ，毎分 $2 l$ の酸素吸入を開始した。血圧 低下時は直ちに生理食塩水を注入し, 血流量や除水量を 減少させてから医師に報告し, 症状観察に努めた。また,

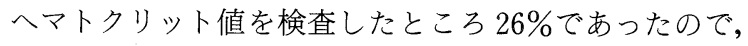
次回に輸血 2 単位の準備をした.

さらにドライウェイトまで除水できない時には主治医 とともに検討し, 溢水状態がなければドライウェイトを 階段状に増加させた。体重増加をできるだけ防ぐため, 塩酸イソクスプリンの高濃度溶液を微量注入に変更し た。 また体外循環量を最小限に押えるため, 血液回路を 小容積回路に変えた．食事は時々嘔吐もあったが十分摂 るように勧めた。病院食全量摂取の他に間食もとり十分 であると考えた。

3 ) 胎児に対する不安（再度未熟肺児が生れる）があ る.

妊娠を継続させることが一番大切であることを説明し てあり, 妊娠 32 週を過ぎ, 胎児の成長も順調であること を知らされてからは明るくなって，妊娠の継続に意欲的 となった。

4）全身搔痒感と長時間透析による苦痛がある.

分婏直後には搔痒感が増強し, 下肢に搔傷がみられた。 時には不眠を訴えることもあったが，眠剤は内服せず日 中に睡眠をとった。搔痒感を軽減させるのに最も効果が
あったのは,局部にアイスノンを貼用したことであった。 長時間透析による苦痛も無視できず, 特に週 4 回・1 回 6 時間の場合に苦痛が激しく, 検査データーを検討して 週 5 回・ 1 回 5 時間に変更し苦痛の緩和ができた。

\section{考察}

我国に扔ける透析患者の出産については, 1977 年に小 林, 大坪らが出産例を初めて報告して以来, 数例報告さ れているにすぎないが，看護面から検討した報告は 2 例 のみである. 森北ら ${ }^{11}$ の報告によれば, 透析歴 3 年目に初 回妊娠, 尿量が 1 日 $300 \mathrm{~m} l$ から $1,700 \mathrm{~m} l$ で羊水過多症 や血圧変動はみられていない，切迫早産症状があり，患 者㧍よび家族が異常出産や異常児に対する不安が強かっ たと述べており, 安静を守らせ, 詳細に観察を行って状 態の把握に努め, 幾分でも不安を取り除くことによって, 妊娠を継続させる援助ができたと報告している.

また高橋)の報告は, 透析歴 15 年目の患者で本症例と 同じく 2 回目の妊娠継続であった. 羊水過多症, 子宮筋 収縮による腹部緊満感などがあり, 本症例と同じように 子宮頸管縫縮術や多量の羊水穿刺を行っている。ささらに この症例では, 食事摂取が十分でなかったこと, 透析中 にイライラ感が強く, 透析量の増加を拒否されたこと, 母親としての自覚不足が問題であったとのことである. また母親教育を行った経験より, 透析患者が妊娠を希望 する場合は, 予想される困難な問題点を十分理解させた 上で，妊娠を許可することが望ましいと報告している。

本症例においても, 子宮筋収縮による腹部緊満感, 羊 水過多症, 肝機能障害, 透析中の血圧低下などの問題が

妊娠30週 2 日目

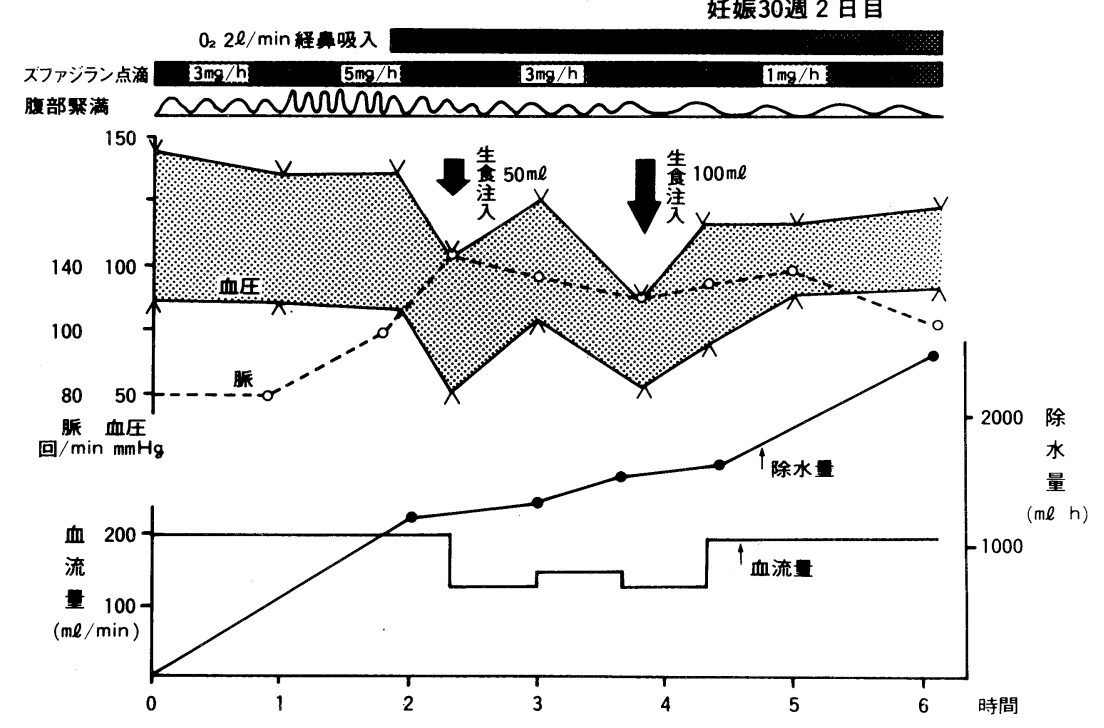

図 2 腹部緊満感と血圧低下がみられた妊娠 30 週 2 日目の透析経過 
あり，妊娠の継続にはいくつかの困難な点があつた。妊 娠 20 週頃から透析中の血圧低下と腹部緊満がみられた が, 注意深い綿密な観察と対応に努めたこと, また胎児 に対する不安や透析中の苦痛をできるかきり緩和させる ことに努力したこと，さらに夫や家族とともに患者を励 ましていったことなどが，妊娠の継続に大きく役立った と考える。また患者自身が挙児願望が非常に強く, 私達 の指導を十分理解できて協力的であったことも, 妊娠を 継続できた一因であると考える．現在のところ退院後の 育児援助者は夫だけであり，透析治療と育児の両立はな かなか容易でないと思われる。今後とも育児相談にもか かわりながら，母児の経過観察に努めたい.

\section{まとめ}

1 ) 慢性透析患者（31 歳, 透析歴 3 年）の 2 回目の妊 娠と分婏を経験したので, 看護面より検討を加えて報告 した。

2 ) 本症例は肝機能障害と羊水過多症が認められ, 羊 水穿刺を合計 11 回 $4,450 \mathrm{~m} l$ 施行した.

3 ）また透析経過中に血圧低下と腹部緊満がみられた が, 注意深い観察に努め, 的確に対処した。

4) $1,802 \mathrm{~g}$ の男児を出産し, 母児ともに順調に経過し ている.

本論文の要旨は, 第 31 回日本透析療法学会にて報告した。

\section{文献}

1）森北夕ッ子，川良玲子，浅野由也，村上マキエ，本 川英子, 伊積美砂子, 田中由美子, 吉岡恵美子：長 期透析患者の妊娠, 出産を経験して。臨床看護, 9： 553-558, 1983.

2）城代明仁, 今村厚志, 来山敏夫, 下前英司, 山田 潤, 草場泰之，金武 洋，進藤和彦，斉藤 泰，原田孝 司，平井義修，大園恵幸，川富正弘，浦 繁郎，原 耕平, 安永昌子, 吉田至誠, 井上正幸 : 長期血液透 析患者の妊娠分婏の 1 例。透析会誌，16：183-187, 1983.

3）高橋美津子：妊娠の透析一妊娠継続のポイント. 臨 床透析, $2: 347-351,1986$.

4）中村 稔，吉谷徳夫，吉沢浩志，湯沢秀夫，金沢浩 二, 竹内正七，鈴木 亨, 下条文武：透析患者の妊 娠, 分婏の 1 例. 日産婦新潟地方部会誌, $34: 55-60$, 1984.

5）東間 紘: 本邦腎不全患者の妊娠と出産一全国アン ケート調査報告。腎と透析，12:585-591， 1982.

6）大坪公子, 大坪 修: 性, 妊娠, 出産, 育児. 日本 臨床, 38：2378-2383，1980。

7）柏村賀子, 池田雅彦, 藤永 隆, 合屋忠信, 藤永三 千代, 橋本武夫, 山口洋一郎, 久永幸生：長期血液 透析中に早産した 1 例. 産婦人科の実際, 31 ： 1967-1971， 1982. 